\title{
Enantioselective Organocatalytic Michael Additions of Aldehydes to Enones with Imidazolidinones: Co-Catalyst Effects and Evidence for an Enamine Intermediate
}

\author{
Timothy J. Peelen, Yonggui Chi, Samuel H. Gellman* \\ Contribution from the Department of Chemistry, University of Wisconsin, Madison, Wisconsin 53706.
}

\section{Supporting Information}

General Procedures. Analytical thin-layer chromatography was carried out on Whatman TLC plates precoated with silica gel 60 (250 $\mu \mathrm{m}$ thickness). Visualization was performed using a UV lamp or potassium permanganate stain. Column chromatography was performed on EM Science silica gel 60 (230-400 mesh).

Materials. Commercial reagents were purchased from Sigma Aldrich, and used as received with the following exception: hydrocinnamaldehyde and octyl aldehyde were distilled prior to use.

Instrumentation. Proton nuclear magnetic resonance $\left({ }^{1} \mathrm{H}\right.$ NMR) spectra were recorded on a Bruker AC-300 (300 MHz) or Varian Inova-500 (500 MHz) spectrometer. Chemical shifts were reported in parts per million (ppm, $\delta$ ) relative to tetramethylsilane ( $\$ 0.00) .{ }^{1} \mathrm{H}$ NMR splitting patterns are designated as singlet (s), doublet (d), triplet (t), or quartet (q). All first-order splitting patterns were assigned on the basis of the appearance of the multiplet. Splitting patterns that could not be easily interpreted are designated as multiplet (m) or broad (br). Carbon nuclear magnetic resonance $\left({ }^{13} \mathrm{C}\right.$ NMR) spectra were recorded on a Bruker AC-300 (75 MHz) spectrometer. Mass spectra (MS) were obtained using an electrospray ionization (ESI) mass spectrometer or an electron impact (EI) mass spectrometer. Optical rotations were measured using a $1 \mathrm{~mL}$ cell with a $1 \mathrm{dm}$ path length on a Perkin-Elmer 241 digital polarimeter and are reported as follows: $[\alpha]_{D}^{\text {rt }}(c$ in g per $100 \mathrm{~mL}$, solvent). The enantiomeric excess (ee) of the products was determined by chiral GC or HPLC analysis of either the corresponding 5-keto carboxylic acids (obtained after Jones oxidation) or the corresponding 5-keto cyclic acetals (obtained after the selective protection of aldehyde) (see below for the general procedures). Chiral GC analysis was performed on a Shimadzu GC-17A gas chromatograph. Chiral HPLC analysis was performed on a Shimadzu 10A instrument.

The MacMillan imidazolidinone, (5S)-5-benzyl-2,2,3-trimethylimidazolidin-4-one hydrochloride (1a-HCl), was prepared using the literature method. ${ }^{1}$ The free base could be isolated by dissolving the salt in sat. $\mathrm{NaHCO}_{3}$, extracting into $\mathrm{CH}_{2} \mathrm{Cl}_{2}(3 \mathrm{x})$, drying over $\mathrm{Na}_{2} \mathrm{SO}_{4}$, and concentrating in vacuo. Imidazolidinones $\mathbf{1 b}$-d were prepared using the analogous procedure using the appropriate ketone and purified as described below:

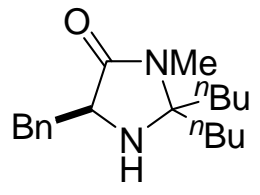

(S)-5-Benzyl-2,2-dibutyl-3-methyl-imidazolidin-4-one (1b) was purified by Kugelrohr distillation of the excess 5-nonanone to yield $1 \mathrm{~b}$ as a colorless oil. The $\mathrm{HCl}$ salt of this imidazolidinone was not crystalline and thus could not be recrystallized: $[\alpha]^{\mathrm{rt}}=-58.3^{\circ}\left(c=1.4, \mathrm{CHCl}_{3}\right) .{ }^{1} \mathrm{H} \mathrm{NMR}\left(300 \mathrm{MHz}, \mathrm{CDCl}_{3}\right) \delta$

\footnotetext{
${ }^{1}$ Ahrendt, K. A.; Borths, C. J.; MacMillan, D. W. C. J. Am. Chem. Soc. 2000, 120, 4243.
} 
7.20-7.33 (m, 5H), $3.82(\mathrm{t}, \mathrm{J}=5.5 \mathrm{~Hz}, 1 \mathrm{H}), 3.02-3.15(\mathrm{~m}, 2 \mathrm{H}), 2.67(\mathrm{~s}, 3 \mathrm{H}), 1.08-1.70(\mathrm{~m}, 11 \mathrm{H})$, $0.87(\mathrm{t}, \mathrm{J}=7.2 \mathrm{~Hz}, 3 \mathrm{H}), 0.78(\mathrm{t}, \mathrm{J}=7.2 \mathrm{~Hz}, 3 \mathrm{H}), 0.55-0.73(\mathrm{~m}, 2 \mathrm{H}) ;{ }^{13} \mathrm{C} \mathrm{NMR}\left(75 \mathrm{MHz}, \mathrm{CDCl}_{3}\right)$ : 174.0, 137.5, 130.0, 128.8, 127.0, 80.2, 60.2, 39.1, 37.8, 37.5, 25.5, 25.5, 24.2, 23.0, 22.8, 14.2, 14.1; TOF-MS-ESI: $[\mathrm{M}+\mathrm{H}]^{+}$calculated 303.2, found 303.3.

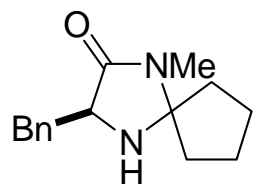

(S)-3-Benzyl-1-methyl-1,4-diaza-spiro[4.4]nonan-2-one (1c) was isolated by precipitation of the $\mathrm{HCl}$ salt from isopropanol upon addition of hexanes. The crude product could be recrystallized by dissolving it in a minimum volume of hot isopropanol, adding hexanes slowly with heating until cloudiness persists, and then adding a minimum volume of isopropanol until the solution becomes homogeneous again: $[\alpha]^{\mathrm{rt}}=-78.4^{\circ}\left(c=1.2, \mathrm{CHCl}_{3}\right) .{ }^{1} \mathrm{H} \mathrm{NMR}\left(300 \mathrm{MHz}, \mathrm{CDCl}_{3}\right) \delta 7.20-7.34(\mathrm{~m}, 5 \mathrm{H}), 3.73(\mathrm{t}$, $\mathrm{J}=5.5 \mathrm{~Hz}, 1 \mathrm{H}), 3.13(\mathrm{dd}, \mathrm{J}=14.1,4.5 \mathrm{~Hz}, 1 \mathrm{H}), 3.04(\mathrm{dd}, \mathrm{J}=14.4,6.6 \mathrm{~Hz}, 1 \mathrm{H}), 2.76(\mathrm{~s}, 3 \mathrm{H})$, 1.83-1.94 (m, 1H), 1.60-1.80 (m, 7H), 1.16-1.23 (m, 1H); ${ }^{13} \mathrm{C}$ NMR $\left(75 \mathrm{MHz}, \mathrm{CDCl}_{3}\right): 174.1$, $137.4,129.7,128.6,126.8,85.9,59.6,37.0,36.9,34.8,25.5,24.0,23.9$; TOF-MS-ESI: $[\mathrm{M}+\mathrm{H}]^{+}$ calculated 245.2, found 245.3.

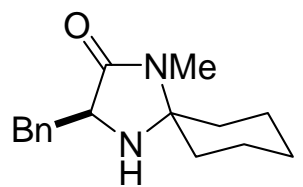

(S)-3-Benzyl-1-methyl-1,4-diaza-spiro[4.5]decan-2-one (1d) was purified by recrystallization of the $\mathrm{HCl}$ salt using an isopropanol/hexanes mixed solvent system: $[\alpha]_{\mathrm{D}}^{\mathrm{rt}}=-76.5^{\circ}\left(c=1.0, \mathrm{CHCl}_{3}\right) .{ }^{1} \mathrm{H} \mathrm{NMR}\left(300 \mathrm{MHz}, \mathrm{CDCl}_{3}\right)$ $\delta$ 7.19-7.34 (m, 5H), $3.76(\mathrm{dd}, \mathrm{J}=6.3,4.2 \mathrm{~Hz}, 1 \mathrm{H}), 3.12(\mathrm{dd}, \mathrm{J}=13.8,4.5 \mathrm{~Hz}$, 1H), 2.99 (dd, J = 13.8, 6.6 Hz, 1H), 2.75 (s, 3H), 1.40-1.70 (m, 9H), 0.89-1.23 (m, $2 \mathrm{H}) ;{ }^{13} \mathrm{C}$ NMR (75 MHz, $\left.\mathrm{CDCl}_{3}\right)$ : 173.7, 137.7, 129.8, 128.6, 126.8, 77.5, 59.3, 38.1, 36.5, 33.8, 25.4, 25.0, 22.7, 22.2; TOF-MS-ESI: $[\mathrm{M}+\mathrm{H}]^{+}$calculated 259.2, found 259.3.

General Procedure 1: Catalytic asymmetric Michael addition to vinyl ketones. To a 1 dram vial equipped with a magnetic stirring bar was add the catalyst (0.2 equiv) and ethyl 3,4dihydroxybenzoate ( 0.2 equiv.). The vinyl ketone (3.0 equiv.) and aldehyde (1.0 equiv.) were added via syringe and the reactions were stirred at room temperature for $20 \mathrm{~h}$. The crude reaction mixture was directly purified by flash column chromatography on silica gel using either hexane/ethyl acetate or pentane/ether mixtures.

General Procedure 2: Preparation of carboxylic acids by Jones oxidation. ${ }^{2}$ To pure keto aldehyde in ether cooled in a bath of cold water was added an aqueous solution of Jones reagent. The cold water bath was removed and the reaction was stirred for $2-18 \mathrm{~h}$. The ether layer was separated and the aqueous layer was extracted with ether $(3 \mathrm{x})$. The combined ether layers were extracted with $3 \mathrm{M} \mathrm{NaOH}(3 \mathrm{x})$. The base extracts were acidified with $3 \mathrm{M} \mathrm{HCl}$ until $\mathrm{pH} 2$. The product was extracted into ether, dried over $\mathrm{MgSO}_{4}$, and concentrated in vacuo. ${ }^{1} \mathrm{H} \mathrm{NMR}$ confirmed that complete oxidation to the carboxylic acid had occurred.

General Procedure 3: Preparation of cyclic acetals by selective acetalization of the aldehyde. ${ }^{3}$ Pure keto aldehydes were dissolved in $\mathrm{CH}_{2} \mathrm{Cl}_{2}$ followed by the addition of 1.1 equiv of propane-1,3-diol and a catalytic amount of $p$-toluensulfonic acid (0.1 equiv). After being stirred for $16 \mathrm{~h}$, the reaction mixture was quenched with $\mathrm{NaHCO}_{3}$. The layers were separated and

\footnotetext{
${ }^{2}$ Rangaishenvi, M. V.; Singaram, B.; Brown, H. C. J. Org. Chem. 1991, 56, 3286.

${ }^{3}$ Melchiorre, P.; Jørgensen, K. A. J. Org. Chem. 2003, 68, 4151.
} 
the aqueous layer was extracted with $\mathrm{CH}_{2} \mathrm{Cl}_{2}(2 \mathrm{x})$, and dried over anhydrous $\mathrm{Na}_{2} \mathrm{SO}_{4}$, and concentrated in vacuo. ${ }^{1} \mathrm{H}$ NMR showed that selective protection of the aldehyde functionality occurred with high chemoselectivity.<smiles>CCC(C=O)CCC(C)=O</smiles>

(R)-2-Ethyl-5-oxo-hexanal (4) ${ }^{4}$ was prepared by the General Procedure 1 using $50.5 \mathrm{mg}$ of $\mathbf{1 c}(0.207 \mathrm{mmol}), 37.7 \mathrm{mg}$ of ethyl 3,4-dihydroxybenzoate (0.207 mmol), $254 \mu \mathrm{L}$ of methyl vinyl ketone $(3.10 \mathrm{mmol})$, and $93 \mu \mathrm{L}$ of butyraldehyde (1.04 mmol). The crude product was purified by flash chromatography with pentane/ $\mathrm{Et}_{2} \mathrm{O}\left(80: 20\right.$ followed by $70: 30, \mathrm{R}_{\mathrm{f}}=0.27,7: 3$ hexanes:EtOAc) to afford $117 \mathrm{mg}$ of the desired product as a colorless oil $(0.825 \mathrm{mmol}, 79 \%)$. $[\alpha]^{\mathrm{rt}}{ }_{\mathrm{D}}=-3.2^{\circ}(c=1.4$, $\mathrm{CHCl}_{3}, 89 \%$ ee). The product was converted to the corresponding carboxylic acid using General Procedure 2 and the enantiomers were separated by chiral GC with use of a Supelco $\beta$-Dex 120 column: T1) $90{ }^{\circ} \mathrm{C}, 10 \mathrm{~min}$; T2) $130{ }^{\circ} \mathrm{C}, 2{ }^{\circ} \mathrm{C} / \mathrm{min}$; T3) $160{ }^{\circ} \mathrm{C}, 1{ }^{\circ} \mathrm{C} / \mathrm{min}$; $\mathrm{T}_{R} 1: 55.1 \mathrm{~min}$ (minor), $\mathrm{T}_{R} 2: 55.5$ min (major).<smiles>CC(=O)CCC(C)C=O</smiles>

(R)-2-Methyl-5-oxo-hexanal (Table 3, entry 1) ${ }^{5}$ was prepared by the General Procedure 1 using $50.5 \mathrm{mg}$ of 1c $(0.207 \mathrm{mmol}), 37.7 \mathrm{mg}$ of ethyl 3,4-dihydroxybenzoate $(0.207 \mathrm{mmol}), 254 \mu \mathrm{L}$ of methyl vinyl ketone $(3.10$ $\mathrm{mmol})$, and $75 \mu \mathrm{L}$ of propionaldehyde $(1.03 \mathrm{mmol})$. The crude product was purified by flash chromatography with pentane/ $\mathrm{Et}_{2} \mathrm{O}\left(80: 20\right.$ followed by $70: 30, \mathrm{R}_{\mathrm{f}}=0.19,7: 3$ hexanes:EtOAc) to afford $111 \mathrm{mg}$ of the desired product as a colorless oil $(0.862 \mathrm{mmol}, 84 \%)$. $[\alpha]_{\mathrm{D}}^{\mathrm{rt}}=+0.7^{\circ}\left(c=1.3, \mathrm{CHCl}_{3}, 90 \%\right.$ ee $)$. The product was converted to the corresponding carboxylic acid using General Procedure 2 and the enantiomers were separated by chiral GC with use of a Supelco $\beta$-Dex 120 column: T1) $90{ }^{\circ} \mathrm{C}, 10 \mathrm{~min}$; T2) $130{ }^{\circ} \mathrm{C}, 2{ }^{\circ} \mathrm{C} / \mathrm{min}$; T3) $160{ }^{\circ} \mathrm{C}, 1$ ${ }^{\circ} \mathrm{C} / \mathrm{min} ; \mathrm{T}_{R} 1: 49.0 \mathrm{~min}$ (minor), $\mathrm{T}_{R} 2: 49.7$ min (major).<smiles>CCC(=O)CCC(C)C=O</smiles>

(R)-2-Methyl-5-oxo-heptanal (Table 3, entry 2) ${ }^{3}$ was prepared by the General Procedure 1 using $54.4 \mathrm{mg}$ of $1 \mathrm{c}(0.223 \mathrm{mmol}), 40.6 \mathrm{mg}$ of ethyl 3,4dihydroxybenzoate $(0.223 \mathrm{mmol}), 331 \mu \mathrm{L}$ of ethyl vinyl ketone $(3.34 \mathrm{mmol})$, and $81 \mu \mathrm{L}$ of propionaldehyde $(1.11 \mathrm{mmol})$. The crude product was purified by flash chromatography with pentane/ $\mathrm{Et}_{2} \mathrm{O}\left(80: 20\right.$ followed by $70: 30, \mathrm{R}_{\mathrm{f}}=0.29,7: 3$ hexanes:EtOAc) to afford $112 \mathrm{mg}$ of the desired product as a colorless oil $(0.788 \mathrm{mmol}, 71 \%)$. $[\alpha]_{\mathrm{D}}^{\mathrm{rt}}=-2.2^{\circ}\left(c=0.93, \mathrm{CHCl}_{3}, 92 \%\right.$ ee $)$. The product was converted to the corresponding carboxylic acid using General Procedure 2 and the enantiomers were separated by chiral GC with use of a Supelco $\beta$-Dex 120 column T1) $90{ }^{\circ} \mathrm{C}, 10 \mathrm{~min}$; T2) $130{ }^{\circ} \mathrm{C}, 2{ }^{\circ} \mathrm{C} / \mathrm{min}$; T3) $160{ }^{\circ} \mathrm{C}, 1$ ${ }^{\circ} \mathrm{C} / \mathrm{min} ; \mathrm{T}_{R} 1: 55.1 \mathrm{~min}$ (minor), $\mathrm{T}_{R} 2: 55.9 \min$ (major).<smiles>CCC(=O)CCC(C=O)CC</smiles>

(R)-2-Ethyl-5-oxo-heptanal (Table 3, entry 3) ${ }^{3}$ was prepared by the General Procedure 1 using $52.8 \mathrm{mg}$ of $1 \mathrm{c}(0.216 \mathrm{mmol}), 39.0 \mathrm{mg}$ of ethyl $3,4-$ dihydroxybenzoate $(0.216 \mathrm{mmol}), 321 \mu \mathrm{L}$ of ethyl vinyl ketone $(3.24 \mathrm{mmol})$, and $97 \mu \mathrm{L}$ of butyraldehyde $(1.08 \mathrm{mmol})$. The crude product was purified by flash chromatography with pentane/ $\mathrm{Et}_{2} \mathrm{O} \quad\left(80: 20\right.$ followed by $70: 30, \quad \mathrm{R}_{\mathrm{f}}=0.40, \quad 8: 2$ hexanes:EtOAc) to afford $114 \mathrm{mg}$ of the desired product as a colorless oil $(0.734 \mathrm{mmol}, 68 \%)$.

\footnotetext{
${ }^{4}$ Duhamel, P.; Hennequin, L.; Poirier, J. M.; Tavel, G.; Vottero, C. Tetrahedron 1986, 42, 4777.

${ }^{5}$ Molander, G. A.; Cameron, K. O. J. Am. Chem. Soc. 1993, 115, 830.
} 
$[\alpha]_{\mathrm{D}}^{\mathrm{rt}}=+8.2^{\circ}\left(c=1.2, \mathrm{CHCl}_{3}, 92 \%\right.$ ee $)$. The product was converted to the corresponding carboxylic acid using General Procedure 2 and the enantiomers were separated by chiral GC with use of a Supelco $\beta$-Dex 120 column: T1) $100{ }^{\circ} \mathrm{C}, 0 \mathrm{~min}$; T2) $140{ }^{\circ} \mathrm{C}, 1{ }^{\circ} \mathrm{C} / \mathrm{min}$; T3) $200{ }^{\circ} \mathrm{C}, 2$ ${ }^{\circ} \mathrm{C} / \mathrm{min} ; \mathrm{T}_{R} 1: 55.2 \mathrm{~min}$ (minor), $\mathrm{T}_{R} 2: 55.6 \min$ (major).<smiles>CCCC(C=O)CCC(C)=O</smiles>

(S)-2-Isopropyl-5-oxo-hexanal (Table 3, entry 4) ${ }^{6,7}$ was prepared by the General Procedure $1 \mathrm{using} 45.7 \mathrm{mg}$ of $1 \mathrm{c}(0.187 \mathrm{mmol}), 34.1 \mathrm{mg}$ of ethyl 3,4-dihydroxybenzoate $(0.187 \mathrm{mmol}), 230 \mu \mathrm{L}$ of methyl vinyl ketone $(2.81$ $\mathrm{mmol})$, and $100 \mu \mathrm{L}$ of isovaleraldehyde $(0.936 \mathrm{mmol})$. The crude product was purified by flash chromatography with pentane/ $\mathrm{Et}_{2} \mathrm{O}\left(80: 20\right.$ followed by $70: 30, \mathrm{R}_{\mathrm{f}}=0.34$, 7:3 hexanes:EtOAc) to afford $80 \mathrm{mg}$ of the desired product as a colorless oil $(0.51 \mathrm{mmol}, 55 \%)$. $[\alpha]_{D}^{\mathrm{rt}}=+24^{\circ}\left(c=1.8, \mathrm{CHCl}_{3}, 82 \%\right.$ ee $)$. The product was converted to the corresponding carboxylic acid using General Procedure 2 and the enantiomers were separated by chiral GC with use of a Supelco $\beta$-Dex 120 column: T1) $100{ }^{\circ} \mathrm{C}, 0 \mathrm{~min}$; T2) $140{ }^{\circ} \mathrm{C}, 1{ }^{\circ} \mathrm{C} / \mathrm{min}$; T3) $200{ }^{\circ} \mathrm{C}, 2$ ${ }^{\circ} \mathrm{C} / \mathrm{min} ; \mathrm{T}_{R} 1: 53.6 \mathrm{~min}$ (minor), $\mathrm{T}_{R} 2: 53.9 \min$ (major).<smiles>CC(=O)CCC(Br)C=O</smiles>

(S)-2-Benzyl-5-oxo-hexanal (Table 3 , entry 6) ${ }^{6}$ was prepared by the General Procedure $1 \mathrm{using} 58.1 \mathrm{mg}$ of $1 \mathrm{c}(0.238 \mathrm{mmol}), 43.4 \mathrm{mg}$ of ethyl 3,4-dihydroxybenzoate (0. $238 \mathrm{mmol}), 293 \mu \mathrm{L}$ of methyl vinyl ketone (3.57 $\mathrm{mmol})$, and $157 \mu \mathrm{L}$ of butyraldehyde $(1.19 \mathrm{mmol})$. The crude product was purified by flash chromatography with pentane/ $\mathrm{Et}_{2} \mathrm{O}\left(80: 20\right.$ followed by $70: 30, \mathrm{R}_{\mathrm{f}}=0.21,8: 2$ hexanes:EtOAc) to afford $151 \mathrm{mg}$ of the desired product as a colorless oil $(0.737 \mathrm{mmol}, 62 \%)$. $[\alpha]_{D}^{\mathrm{rt}}=-0.37^{\circ}\left(c=1.6, \mathrm{CHCl}_{3}, 89 \%\right.$ ee $)$. The product was converted to the corresponding propanediol monoacetal using General Procedure 3 and the enantiomers were separated by HPLC using a Chiracel OD column $\left(85 / 15\right.$ hexane $/ i-\mathrm{PrOH}$; flow rate $0.5 \mathrm{~mL} / \mathrm{min} ; \mathrm{T}_{R} 1: 30.2 \mathrm{~min}$ (major), $\mathrm{T}_{R} 2: 36.7 \mathrm{~min}$ (minor).<smiles>CCC(=O)CCC(Br)C=O</smiles>

(S)-2-Benzyl-5-oxo-heptanal (Table 3, entry 7) ${ }^{6}$ was prepared by the General Procedure 1 using $49.1 \mathrm{mg}$ of $1 \mathrm{c}(0.201 \mathrm{mmol}), 36.6 \mathrm{mg}$ of ethyl 3,4dihydroxybenzoate $(0.201 \mathrm{mmol}), 299 \mu \mathrm{L}$ of ethyl vinyl ketone $(3.02 \mathrm{mmol})$, and $133 \mu \mathrm{L}$ of hydrocinnamaldehyde $(1.01 \mathrm{mmol})$. The crude product was purified by flash chromatography with pentane/ $\mathrm{Et}_{2} \mathrm{O}\left(80: 20\right.$ followed by $70: 30, \mathrm{R}_{\mathrm{f}}=0.33,8: 2$ hexanes:EtOAc) to afford $120 \mathrm{mg}$ of the desired product as a colorless oil $(0.550 \mathrm{mmol}, 54 \%)$. $[\alpha]_{D}^{\mathrm{rt}}=-1.7^{\circ}\left(c=1.9, \mathrm{CHCl}_{3}, 92 \%\right.$ ee $)$. The product was converted to the corresponding propanediol monoacetal using General Procedure 3 and the enantiomers were separated by HPLC using a Chiracel OD column $\left(92 / 8\right.$ hexane $/ i-\mathrm{PrOH}$; flow rate $1.0 \mathrm{~mL} / \mathrm{min} ; \mathrm{T}_{R} 1: 19.0 \mathrm{~min}$ (major); $\mathrm{T}_{R} 2: 23.7 \mathrm{~min}$ (minor).

Assignment of keto aldehyde stereochemistry: The absolute stereochemistry was assigned for (S)-2-isopropyl-5-oxo-hexanal by comparing the sign of the optical rotation to the same compound reported in the literature, which had been synthesized from limonene. ${ }^{7}$ All other compounds were assigned by analogy to this compound. The GC profile of the carboxylic acids

\footnotetext{
${ }^{6}$ Hagiwara, H.; Komatsubara, N.; Ono, H.; Okabe, T.; Hoshi, T.; Suzuki, T.; Ando, M.; Kato, M. J. Chem. Soc. Perkin Trans. 1 2001, 316.

${ }^{7}$ Hudlicky, T.; Fleming, A.; Radesca, L. J. Am. Chem. Soc. 1989, 111, 6691.
} 
derived from related keto aldehydes matched that observed for the carboxylic acid derived from $(S)$-2-isopropyl-5-oxo-hexanal (minor enantiomer eluting first). It should be noted that in two cases (4 and (R)-2-methyl-5-oxo-heptanal) the optical rotations we measured were of the opposite sign relative to those reported for the same enantiomer by Jørgensen. ${ }^{3}$ However, in these cases the magnitudes of the rotations were very small, and the differences may be within experimental error.

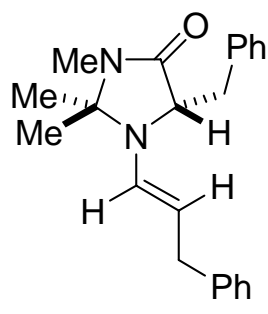

Preparation of Enamine 6: To $389 \mathrm{mg}(1.78 \mathrm{mmol})$ of (5S)-5-benzyl-2,2,3trimethylimidazolidin-4-one (1a) in $5 \mathrm{~mL}$ of dry d6-DMSO ${ }^{8}$ was added $177 \mathrm{uL}$ $(1.34 \mathrm{mmol})$ hydrocinnamaldehyde and $3 \mathrm{~g}$ of freshly activated $4 \mathrm{~A} \mathrm{MS}^{9}$ The reaction was allowed to sit at room temperature without stirring for 1 week. ${ }^{1} \mathrm{H}$ NMR revealed complete conversion of the aldehyde to the desired enamine (the excess 1a was also observed). ${ }^{1} \mathrm{H}$ NMR (300 MHz, $\mathrm{D}_{6}$-DMSO) $\delta$ 7.10-7.34 (m, $8 \mathrm{H}), 6.98(\mathrm{dd}, \mathrm{J}=7.5,1.5 \mathrm{~Hz}, 2 \mathrm{H}), 6.31(\mathrm{~d}, \mathrm{~J}=14.1 \mathrm{~Hz}, 1 \mathrm{H}), 4.53(\mathrm{dt}, \mathrm{J}=14.1$, $6.9 \mathrm{~Hz}, 1 \mathrm{H}), 3.99(\mathrm{~d}, \mathrm{~J}=3.9 \mathrm{~Hz}, 1 \mathrm{H}), 3.30-3.42(\mathrm{~m}, 2 \mathrm{H}), 3.13(\mathrm{dd}, \mathrm{J}=13.5,5.4 \mathrm{~Hz}, 1 \mathrm{H}), 2.88$ (dd, J = 13.2, 1.8 Hz, 1H), 2.57 (s, 3H), 1.23 (s, 3H), 0.70 (s, 3H).

\footnotetext{
${ }^{8}$ To ensure dryness, we used freshly opened $1 \mathrm{~mL}$ ampoules.

${ }^{9}$ 4-8 mesh beads were used. Impurities were observed if ground 4A MS were used.
} 


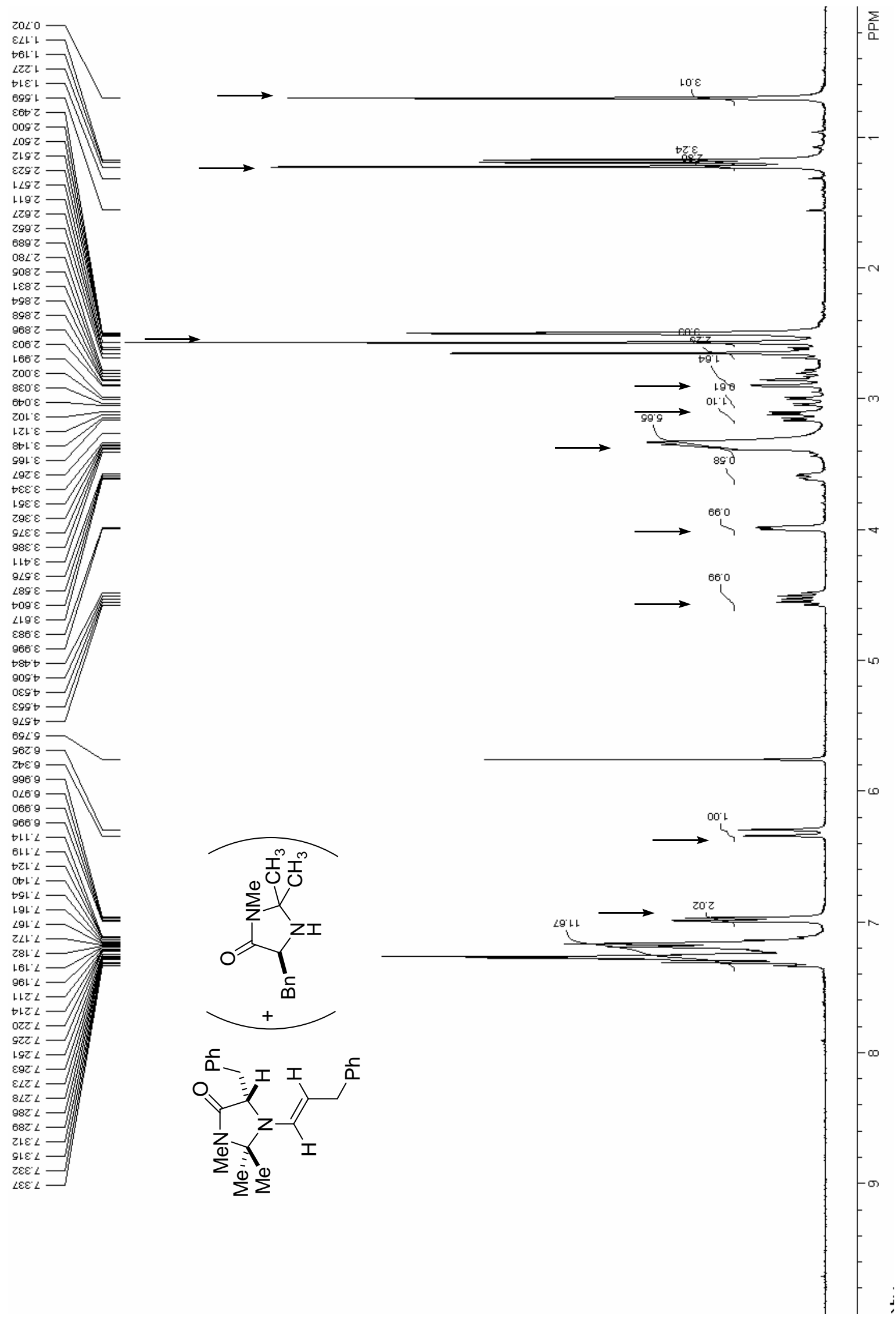



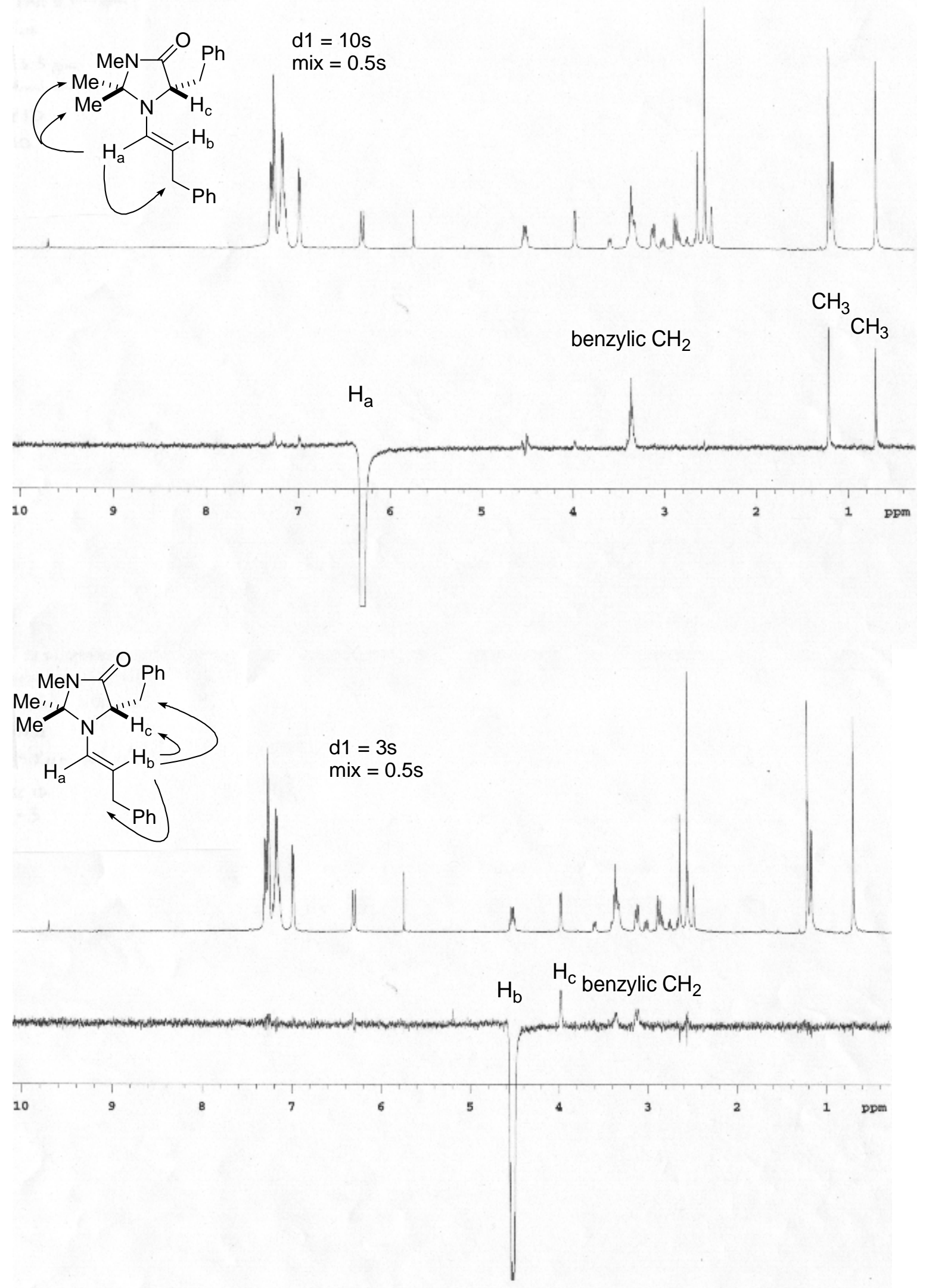
Reaction of enamine 6: Enamine 6 was prepared as described above and was concentrated by Kugelrohr distillation to generate approximately $0.25 \mathrm{mmol}$ of neat enamine (along with additional imidazolidinone 1a) as a colorless oil. To this oil was added $63 \mu \mathrm{L}$ of methyl vinyl ketone $(0.75 \mathrm{mmol})$ and $9 \mathrm{mg}$ of ethyl 3,4-dihydroxybenzoate $(0.05 \mathrm{mmol})$. Aliquots were removed from the reaction periodically, dissolved in d6-DMSO, and immediately analyzed by ${ }^{1} \mathrm{H}$ NMR.
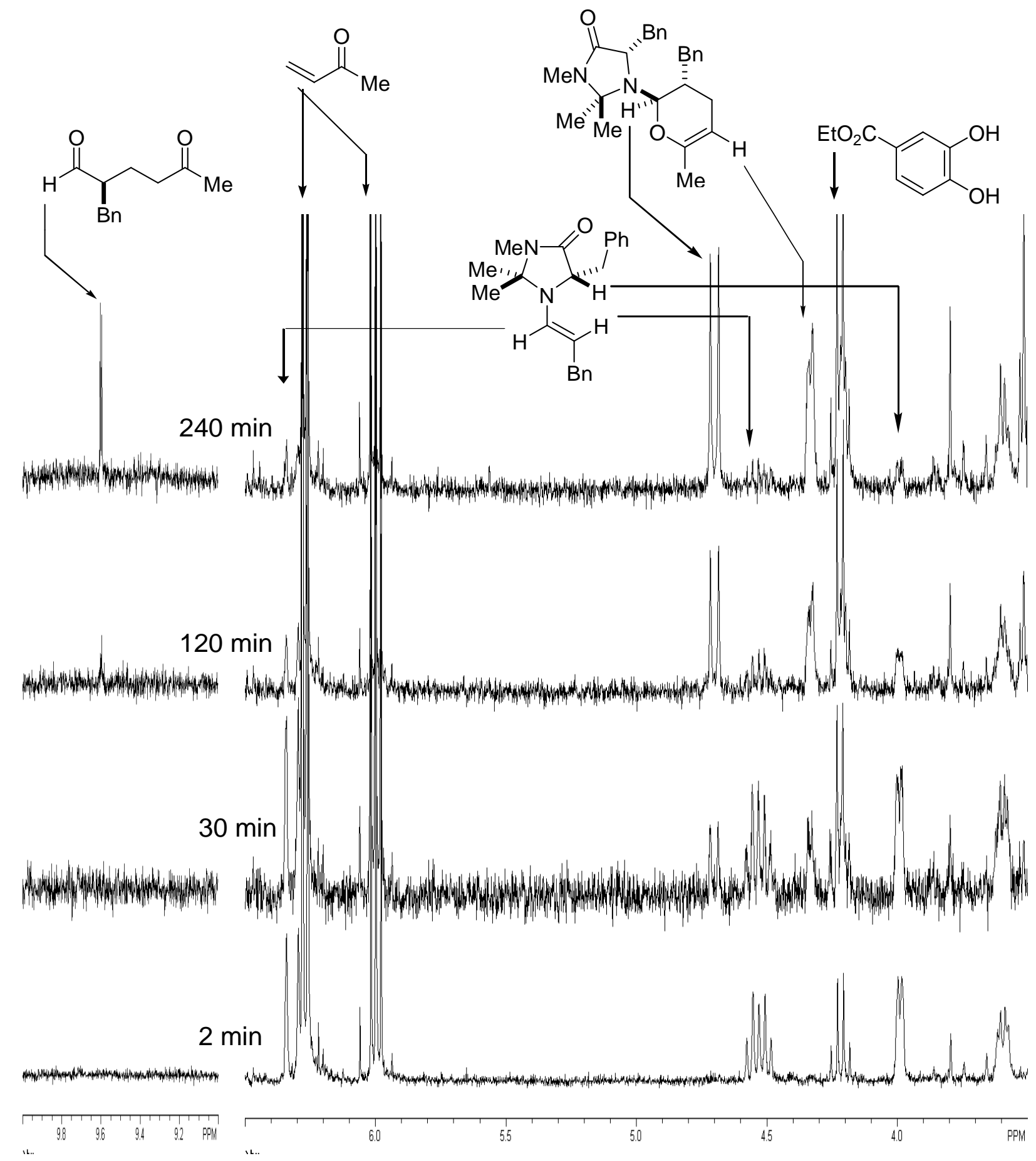
Assignment of structure and stereochemistry of dihydropyranone 8: Dihydropyranone 8 was assigned based on 1D NOESY and TOCSY experiments of the $240 \mathrm{~min}$ aliquot show above. TOCSY experiments (irradiation of the doublet at $4.68 \mathrm{ppm}$ ) revealed gradual elaboration of a spin system consistent with the dihydropyran core. 1D NOESY experiments revealed contacts with two singlets consistent with the methyl groups attached to the imidizolidinone ring. The absolute chemistry at $\mathrm{H}_{b}$ is assigned according to the stereochemistry of the product. The $\mathrm{H}_{\mathrm{a}}, \mathrm{H}_{\mathrm{b}}$ trans stereochemistry is assigned based upon the $9.5 \mathrm{~Hz}$ coupling constant, which is very close to the coupling constant $(\mathrm{J}=8.8 \mathrm{~Hz})$ observed in a similar trans dihydropyranone ${ }^{10}$, and far from the 2.6-3.0 Hz coupling constants observed in similar cis dihydropyranones. ${ }^{11}$

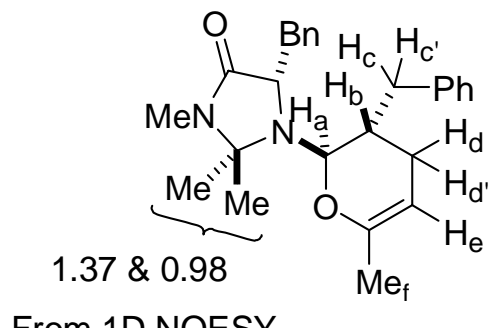

From TOCSY:

$\mathrm{H}_{\mathrm{a}}: 4.68(\mathrm{~d}, \mathrm{~J}=9.5 \mathrm{~Hz})$

$\mathrm{H}_{\mathrm{b}}: 2.00-2.09(\mathrm{~m})$

$\mathrm{H}_{\mathrm{C}} \& \mathrm{H}_{\mathrm{c}^{\prime}}: 2.11(\mathrm{t}, \mathrm{J}=12.5 \mathrm{~Hz}), 3.26(\mathrm{~d}, \mathrm{~J}=13.5 \mathrm{~Hz})$

$H_{d} \& H_{d^{\prime}}: 1.50-1.60(m), 1.65-1.75(m)$

$\mathrm{H}_{\mathrm{e}}: 4.31(\mathrm{~d}, \mathrm{~J}=6.5 \mathrm{~Hz})$

$\mathrm{Me}_{\mathrm{f}}: 1.61$ (s)

\section{From 1D NOESY}

$\operatorname{mix}(\mathrm{s})$

0.15

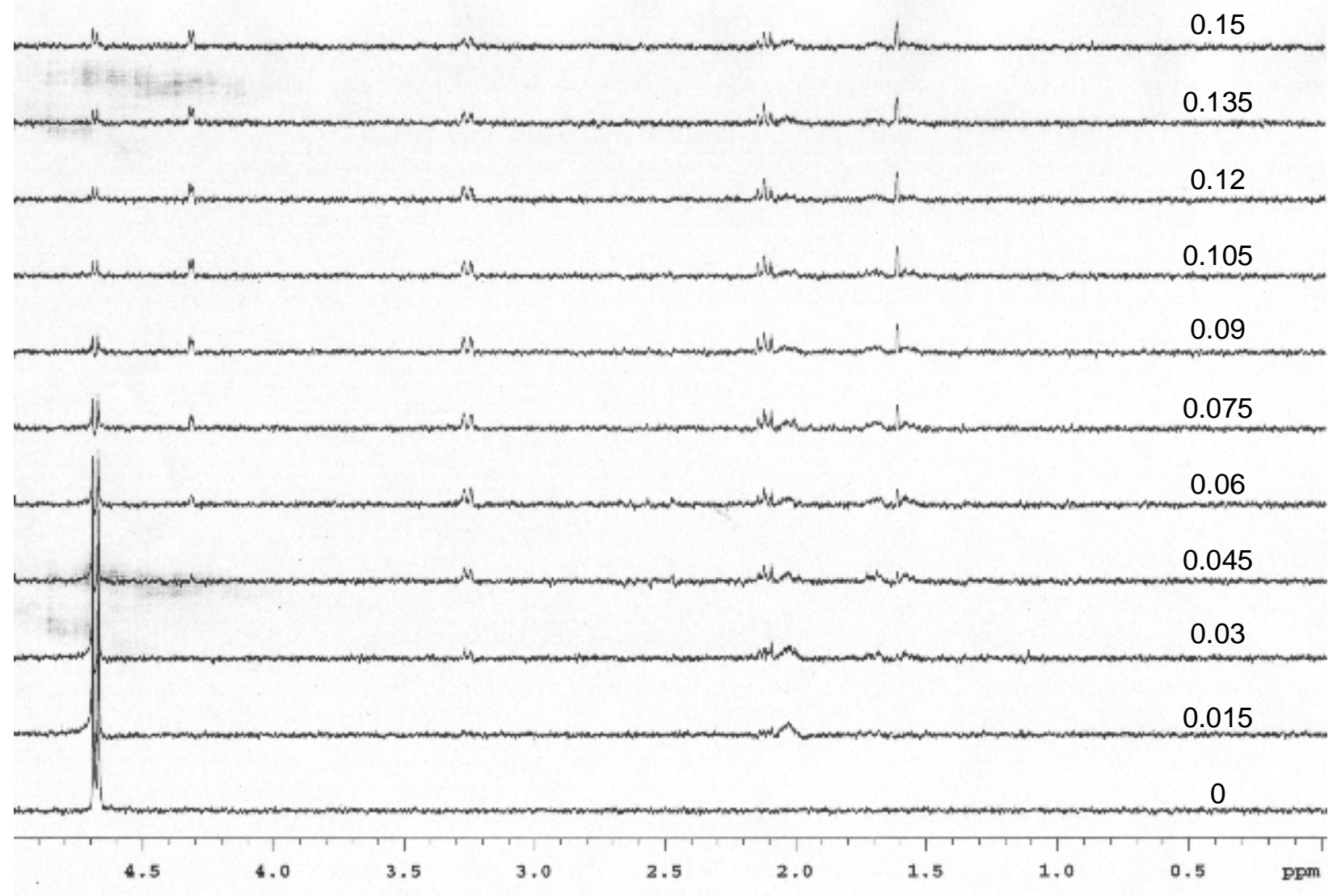

${ }^{10}$ Birkofer, L.; Quittmann, W. Chem. Ber. 1986, 119, 257.

${ }^{11}$ Shibata, Y.; Kosuge, Y.; Ogawa, S. Carbohyd. Res. 1990, 199, 37. Gallagher, T. F.; Horton, D. Carbohyd. Res. 1983, 116, 227. 


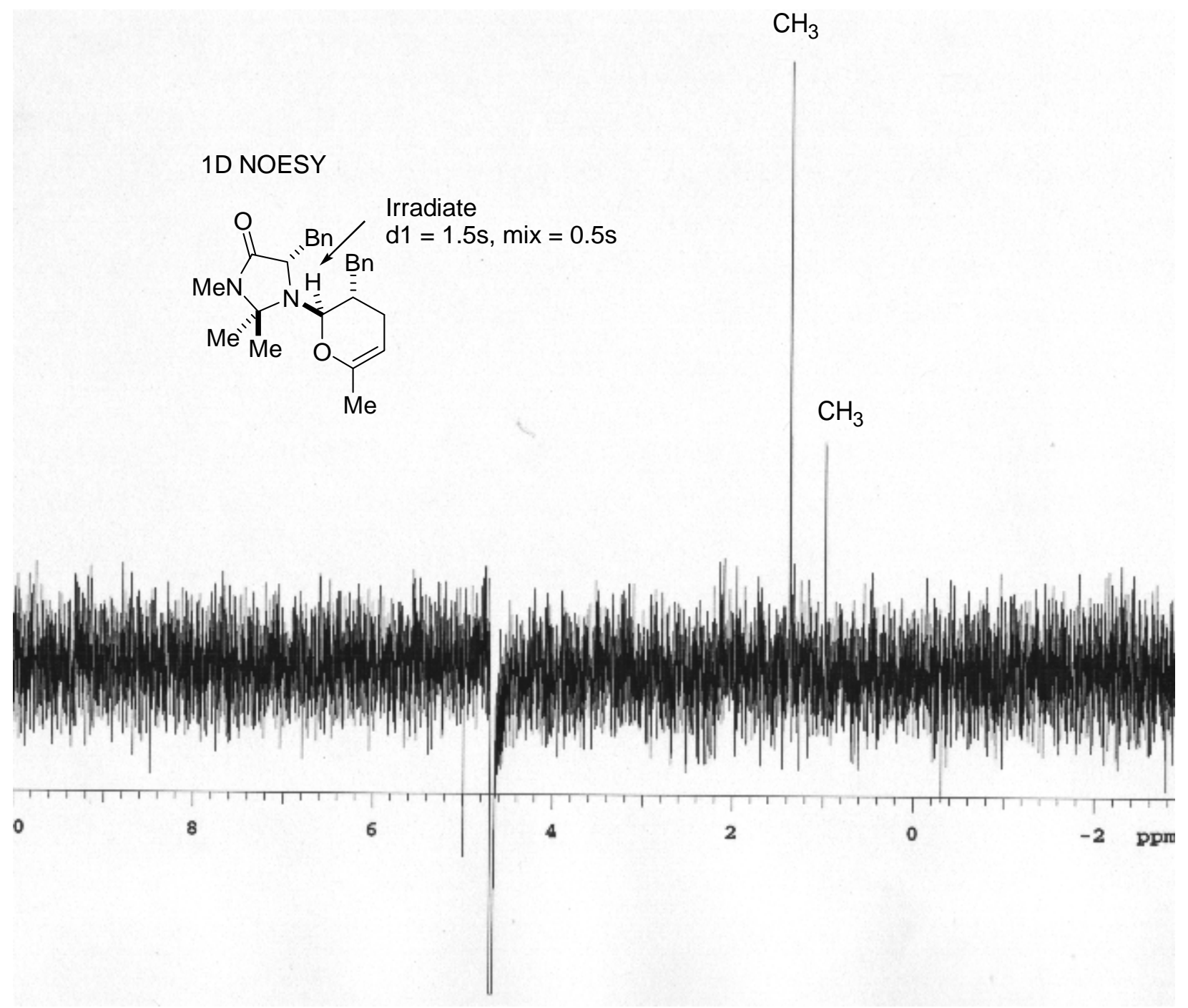



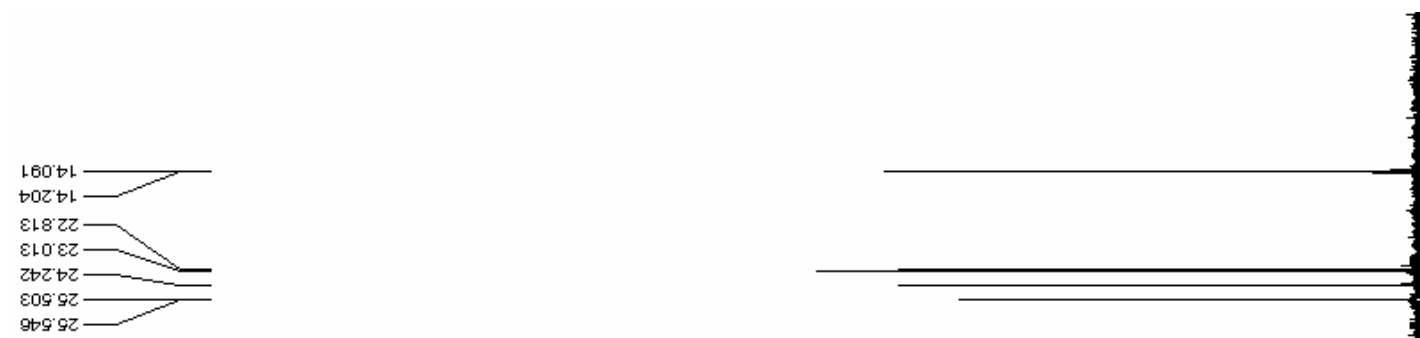

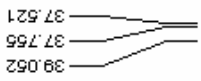

$66+\cdot 09$
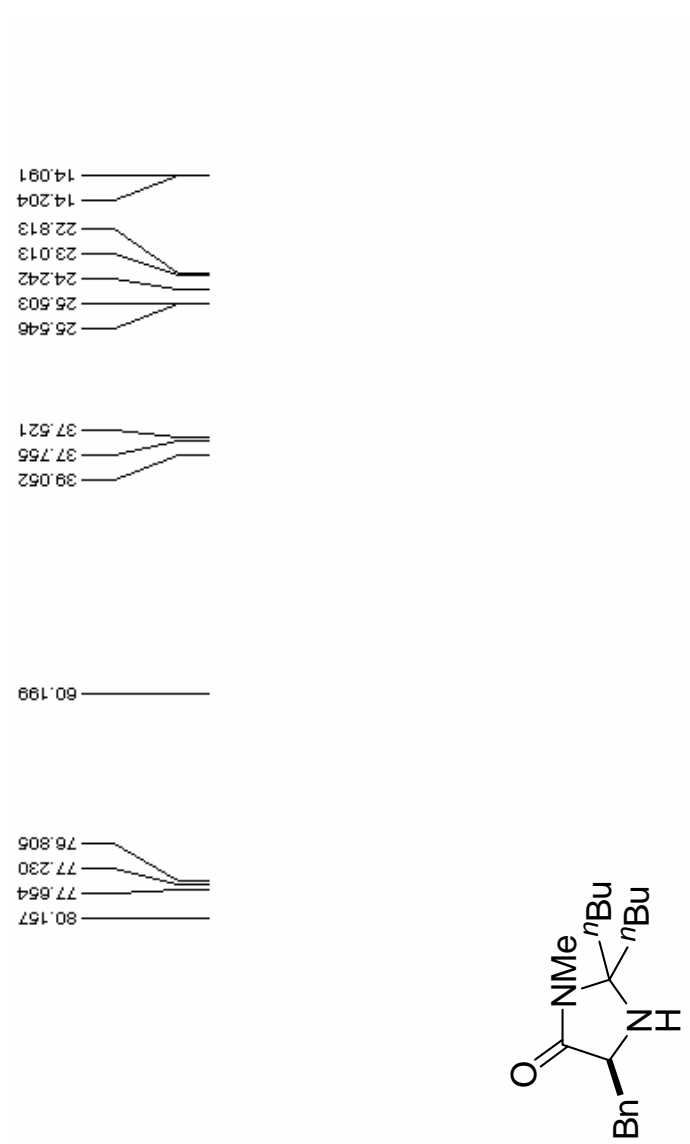

$\circ G 9^{\circ} \angle L$
$\angle G L^{\circ} 08$

$800 \angle Z$

L8L' $8 \mathrm{ZL}$

$99 t^{\circ} \angle \varepsilon+$

$Z 86^{\prime} \varepsilon \angle 1$

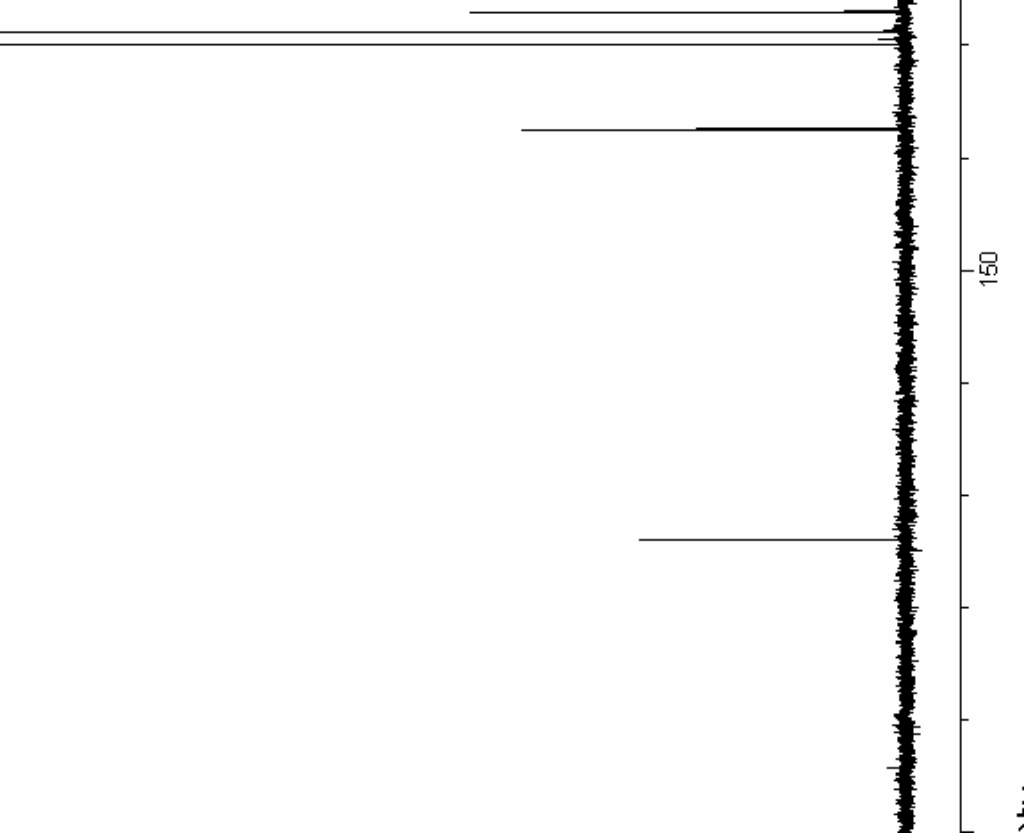

S-11 


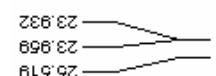

$6968 z$

$68 \angle t \circ$

$0 \varepsilon 6.98$

$0 \varepsilon 0<\varepsilon=$

19969

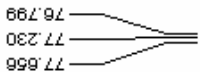

$0<898$
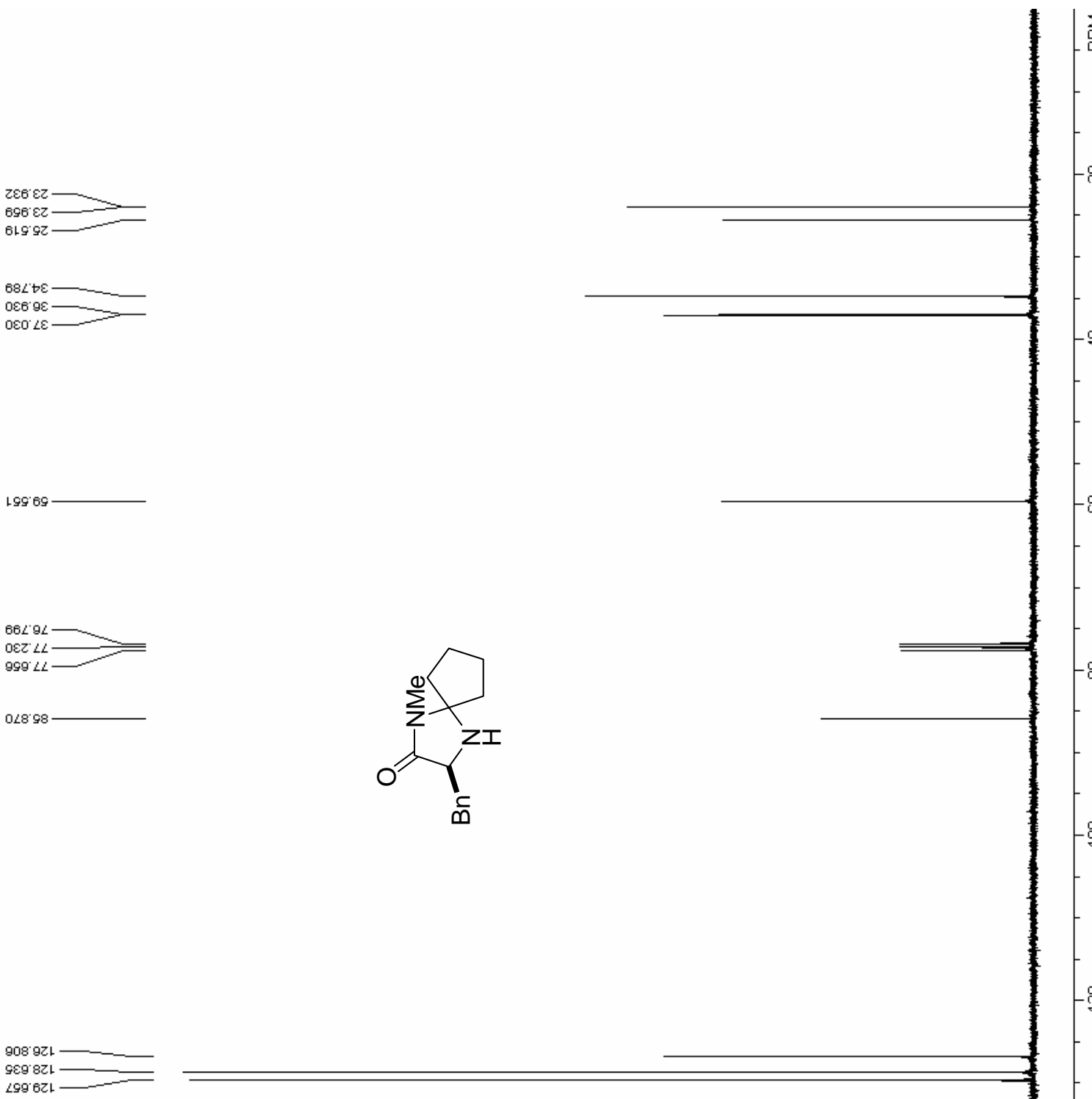

$\downarrow 8 \varepsilon: \varepsilon\llcorner$

ozt. $t<L$

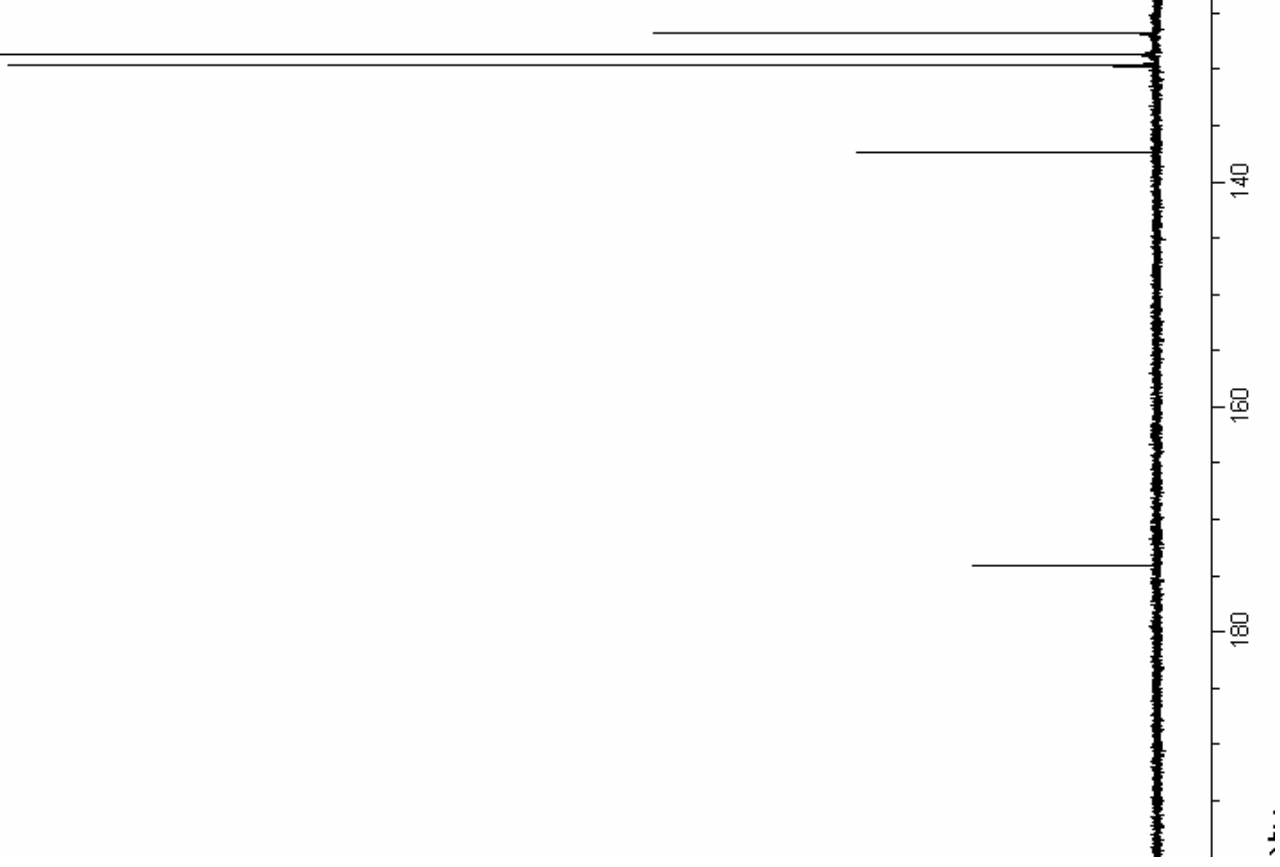

S-12 
ot $z z z$

$8 \varepsilon L z z$

$600 \mathrm{gz}$

$8 L \varepsilon g z$

เว\& $\varepsilon \varepsilon$

$8 \rightarrow 9 \cdot 9 \varepsilon$
$z 90 \cdot 8 \varepsilon$

$98 z 69$

$808 \cdot 9 \angle$

get $\angle L \longrightarrow \longrightarrow$ 890

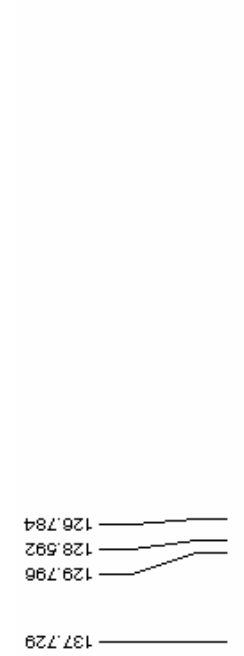

$\varepsilon L \angle \varepsilon L L$
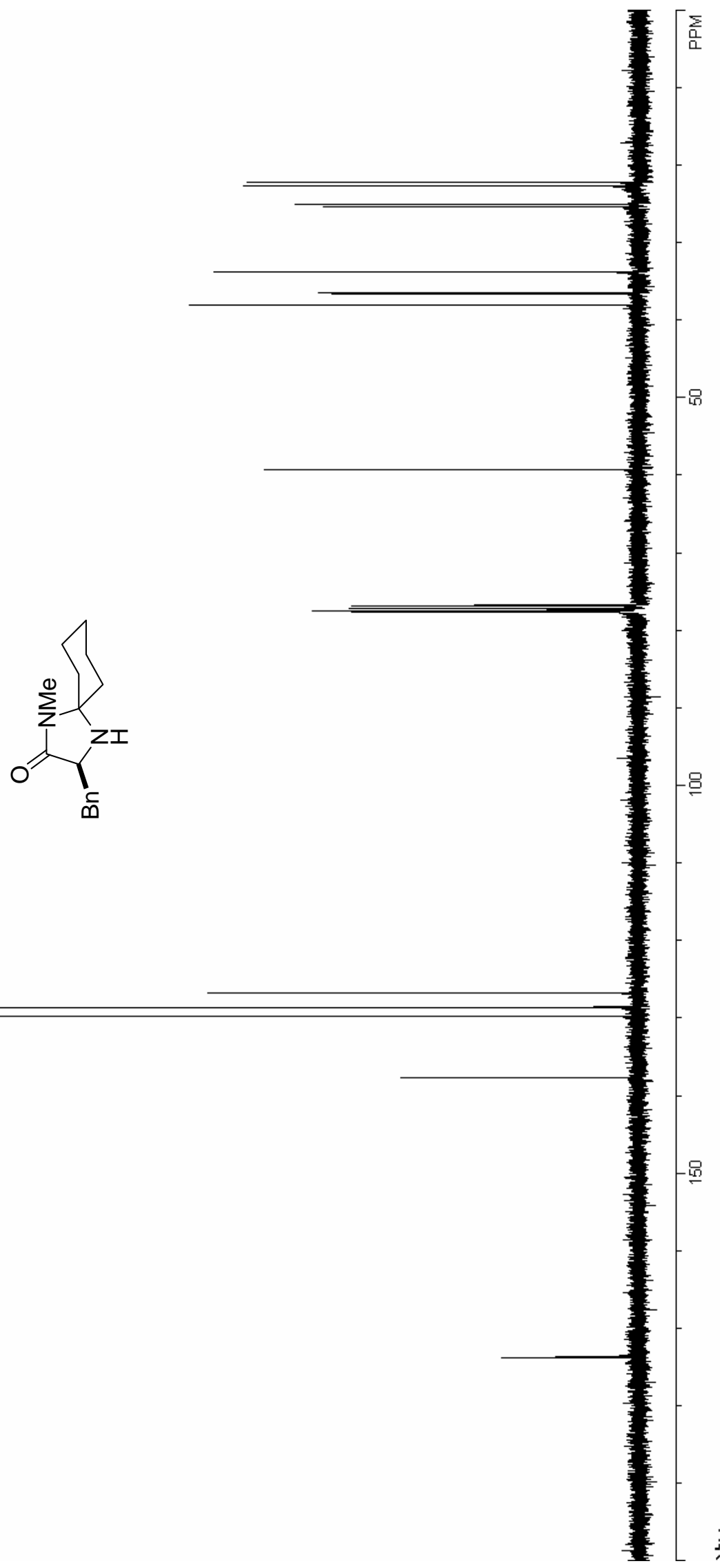

S-13 